\section{HOW UNIVERSITY GRADUATION \\ SHAPES ATTITUDES TOWARD \\ EMPLOYMENT IN DIFFERENT \\ GENERATIONS OPERATING AT JOB MARKET?}

\begin{abstract}
The article deals with the evaluation of university graduates' attitudes towards job characteristics based on their generation. Research shows that the attitudes of individuals in the labor market are currently changing. However, the question is to what extent this change is related to the entry of a new generation or to what extent generational affiliation plays a role in the different attitudes of individuals in the labor market. Therefore, the aim is to test the proposition whether the age of a graduate, respectively his / her affiliation to the generation $X, Y$ or $Z$ affects attitudes towards job characteristics. The partial goal of the article is to identify the main attitudes of searched generations to employment, the second partial goal is to identify attitudes to the evaluation of the benefits of university study in relation to employment. This paper evaluates data from the case study of a selected business university. The return rate of primary survey was representative for the graduates of the case university. The results obtained were statistically tested. Analysis of differences between age and selected factors was used. The analysis showed statistically significant differences between members of generation $X, Y$ and $Z$ in all investigated factors.
\end{abstract}

\section{KEYWORDS}

Age, attitudes, generation, graduate, job position, business university

\section{HOW TO CITE}

Šnýdrová M., Depoo L., Šnýdrová I. (2021) 'How University Graduation Shapes Attitudes Toward Employment in Different Generations Operating at Job Market?', Journal on Efficiency and Responsibility in Education and Science, vol. 14, no. 3, pp. 143-153. http:// dx.doi.org/10.7160/eriesj.2021.140302

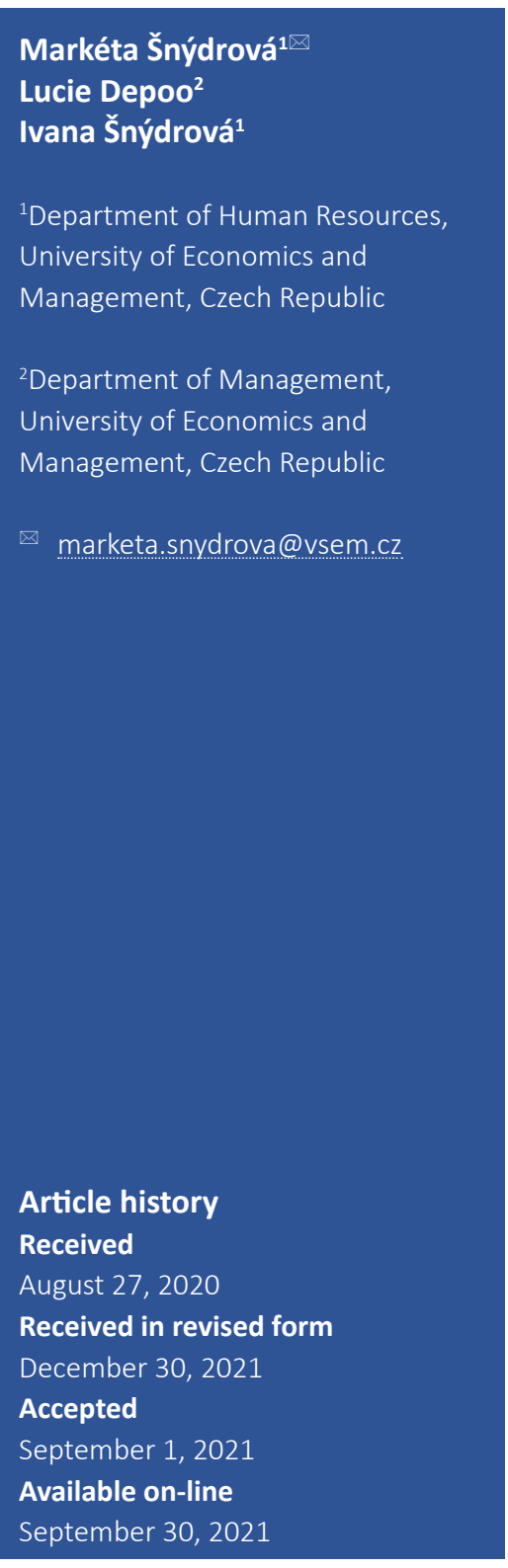

\title{
Highlights
}

- The paper brings empirical validation of generational theory, examining influence on generation $X, Y$ and $Z$.

- Statistically significant differences were confirmed between members of generation $X, Y$ and $Z$ in attitudes toward job position.

- Higher education plays important role in shaping the requirements on graduates' abilities in current work environment.

- Adoption of multi-group analysis informed how generation influence employee attitudes.

\section{INTRODUCTION}

Currently, there are significant changes in the labor market. These changes are related not only to the COVID-19 pandemic but according to some authors (e.g. GadomskaLila, 2020, Yogamalar and Samuel, 2016; Becton, Walker and Jones-Farmer, 2014) mainly to the generational change of the workforce. According to research, generational differences are shown mainly in attitudes (Anderson et al., 2017, Becton, Walker and Jones-Farmer, 2014), but also in competencies and experiences (Gadomska-Lila, 2020). But is a change in attitudes to employment really only the result of a generational change? Does it play a primary role for the baby boomers to retire and the new $\mathrm{Z}$ generation to enter the market? What role does education play in attitudes?

Generation $\mathrm{Z}$ has completely different wishes, visions and requirements than members of previous generations. On the other hand, the same evaluation of the new generation appeared in the evaluation of members of generation Y, entering the labor market and before it was mentioned regarding members of generation $\mathrm{X}$ and previous generations 
(Campbell, Twenge and Campbell, 2017). The issue of changing attitudes towards employment thus comes to the forefront of scientific interest. Indeed, research shows that belonging to a certain generation plays a significant role in the attitudes of its members (Campbell, Twenge and Campbell, 2017; Gadomska-Lila, 2020). To understand the attitudes held by individual generations, it is necessary to understand what attitudes are prevalent for individual generations (GadomskaLila, 2020). It is the sharing of common values and attitudes that is considered an integrative and motivating factor within the organization, and recognizing employee values becomes a key prerequisite for retaining employees in an organization and for increasing work performance of individuals and groups (Gadomska-Lila, 2020). On the contrary, different values often cause conflicts and may possibly lead to a reduction in the effectiveness of teamwork and demotivation. Yi et al (2015) mention that generational differences in values and attitudes can be viewed both globally and from the point of view of individual cultures.

This article focuses on the comparison of attitudes and approaches of university graduates in relation to employment for members of generations $\mathrm{X}$ and $\mathrm{Y}$, which are the most numerous in the labor market, and members of generation $\mathrm{Z}$, which is the emerging generation. Numerous researches focus on the relationship between age and employability (Raemdonck et al., 2015). However, Krahn and Galambos (2013) report that although this number of researches concerning differences in the evaluation of employment factors and different values between generation $\mathrm{X}, \mathrm{Y}$ and generation $\mathrm{Z}$, this area still needs further investigation. In assessing generation differences, employers need to focus primarily on members of the $\mathrm{X}$ and $\mathrm{Y}$ generations, as they are the two largest generations active in the current labor market (Glazer Mahoney and Randall, 2019) and generation $\mathrm{Z}$, which is entering the job market.

Research shows that people of different generations have different attitudes and different job requirements (Yi et al, 2015; Mavromaras and McGuiness, 2012 The aim of the article is to test the proposition whether the age of a graduate, respectively his / her affiliation to the generation $\mathrm{X}, \mathrm{Y}$ or $\mathrm{Z}$ affects attitudes towards job characteristics. The partial goal of the article is to identify the main attitudes of searched generations to employment, the second partial goal is to identify attitudes to the evaluation of the benefits of university study in relation to employment. The data were obtained by a questionnaire survey among members of generations $\mathrm{X}, \mathrm{Y}$ and $\mathrm{Z}$.

\section{Theoretical Background}

This chapter introduces generations $\mathrm{X}, \mathrm{Y}$ and $\mathrm{Z}$ their approach to work and their requirements for a work position, respectively preferred job placement are presented with respect to the factors, which are related to the main identified differences between generations. The differences identified in this chapter will be used for the evaluation of results and discussion of this article. Because the article deals with the issue of employment of generations $\mathrm{X}, \mathrm{Y}$ and $\mathrm{Z}$ it is therefore necessary to specify the term generation. Generation is a group of people born in the same time period, growing up in the same conditions and influenced by the same historical, economic, political and other circumstances (Campbell, Twenge, and Campbell, 2017, Yagamalar and Samuel, 2016, Shragay and Tziner, 2011).

The generation cohort theory is based on the assumption that the same period of birth determines that people experience the same social changes and have similar experiences during childhood and adolescence, which then shapes the whole group and causes a consensus in their views, attitudes and behavior. (Campbell, Twenge, and Campbell, 2017; Yagamalar and Samuel, 2016; Lee and Haley, 2020). An interesting fact in this context is that members of different generations often interpret different periods of life in different ways, although all phases of life go through all people, such as starting the first job, leaving school, etc. (Lee and Haley, 2020). Subsequently, it is necessary to define the investigated generations.

However, it can be perceived as a problem that different authors differ in determining the time span of individual generations. As a result, individual generations overlap in places, and defining differences can be misleading. It is, therefore, necessary to begin by asking whether these are really only generational differences or whether these differences are caused or significantly affected by changes in the living and working conditions of the individuals concerned. In this context, it is possible to mention the assumption that an individual's views can be influenced both by belonging to a certain generation and by his / her age (Lyons and Kuron, 2013; Lyons, Scheitzer and $\mathrm{Ng}, 2015$ ). However, the theory of generations is based on the assumption that the dominant factor is the year of birth of an individual (Lee and Haley, 2020; Rani and Samuel, 2016; Lyons, Scheitzer and $\mathrm{Ng}, 2015)$.

\section{Periods of generation $X$ and $Y$ and $Z$ Generation X}

Generation $\mathrm{X}$ is the generation of people born after the generation known as Baby Boomers (post-war generation). Its timing is not entirely clear, for example, Kopecký (2013) states that it includes individuals born between 1964 and 1975, but Krahn and Galambos (2014) rank it between 1970 and 1980. Other authors such as Kuron et al. (2015) uses period between 1965 and 1979, Gurau (2012) means years between 1961 and 1979, Gadomska-Lila (2020) includes years 1965-1979. This generation is often referred to as the Sandwich generation. This article defines the years 1964-1975.

\section{Generation $Y$}

Generation $\mathrm{Y}$ is the generation following generation $\mathrm{X}$. Malik and Khera (2014) include years between 1981 and 2000; Petro (2013) also mentions 1981 to 2000; Schultz and Schwepker (2012) classify this generation in 1980 to 1993, Gurau (2012) classify it between 1980 and 1999; Kopecký (2013) ranks it in the period 1976 to 2000. In contrast, $\mathrm{Ng}$ and Jonson (2016) mention the years 1980-1995, Gadomska-Lila (2020) includes the years 1980-1995 etc. This generation is often referred to as the Millennials (Lyons and Kuron, 2014).

In this article, generation Y is defined between the years 1976 and 1995. 


\section{Generation Z}

Generation $\mathrm{Z}$ includes individuals born in the digital age who are used to the interconnected world of social networks and the Internet, where they spend a large percentage of their time. Internet and social networks are also their main source of entertainment. They emphasize multiculturalism and individualism, are self-confident, empathetic and inclined to self-esteem. They tend to prefer fast action rather than accuracy (Moravcová-Školudová and Vlčková, 2018; Bláha, Horváthová and Čopíková 2016). Generation Z, like other generations, is defined differently by different authors. Moravcová-Školudová and Vlčková, (2018) or Bláha, Horváthová and Čopíková (2016) define it between the years 1996-2010, but Schroth (2019) states the range of 1997-2013. Generation $\mathrm{Z}$ is a generation that can be described as a digital generation, sometimes even called e-generation. This is a generation that has been spending time on social networks since their childhood. Generation Z has been using social networks as primarily communication channel (Bencsik, Horváth-Csikós and Juhász, 2016).

Within this article, generation $\mathrm{Z}$ is defined as the years 19962010.

Based on the above information, it is, therefore, possible to present the generations that are the subject of the study as follows in Table 1.

\begin{tabular}{c|c}
\multicolumn{1}{c|}{ Generation } & Period \\
\hline Generation X & 1964-1975 \\
\hline Generation Y & 1976-1995 \\
\hline Generation Z & 1996-2010 \\
\hline
\end{tabular}

Table 1: Generation division (source: own processing based on Bláha, Horváthová and Čopíková, 2016; Kopecký, 2013)

The Table 1 introduces that while members of generations $\mathrm{X}$ and $\mathrm{Y}$ are all at the age that places them in the positions of active participants in the labor market, some individuals from generation $\mathrm{Z}$ are still in their childhood and in the labor market we can meet this generation in their age between 18 and 25, i.e., individuals at the very beginning of their working career.

\section{The Attitudes of generation $X, Y$ and $Z$ to Employment}

Each generation has its values and attitudes to employment. Their identification is important for employers who want to achieve the alignment of employee values with the values of the organization, to achieve greater efficiency of the organization and be able to stabilize its personnel. Knowledge of these attitudes will also lead to the elimination of possible conflicts of attitudes between individual generations (Yi et al, 2015). Generational differences between employees are a major challenge for managers, especially when it comes to attitudes (Benson and Brown, 2011). According to Horváthová and Čopíková (2015), there are several differences between the views of those generations on employment. It can be stated that values express a specific relationship of an individual to persons, things and situations. The level of which is the attitude of favor or adversity, desire or rejection or love and hate. Each individual has his / her own individual system of values which is made up of values that the individual considers important. What is important to one may not have value to another. Likewise, the evaluation of values differs in terms of significance and importance. Attitudes are formed based on our values (Gadomska-Lila, 2020). Attitudes towards work are influenced by the importance the individual attaches to his work and how he understands company values. Related to this is the fact that if there is a harmony between the individual values of the individual and the company's values, as part of the company's culture, there is an increase in motivation, commitment and loyalty of the employee (Yogamalar and Samuels 2016). Students' attitude towards job and employment usually depends on the individuals' value of his/ her job and thus it is necessary to understand each employee or potential employee's values. Examples of different attitudes to employment and emerging positions include access to work-life balance, career development opportunities, financial rewards, participation in decision-making, etc. (Anderson et al., 2017). However, differences also appear in the very approach to work, the way of communication and the whole world. Benson and Brown (2011) found that generation $\mathrm{X}$ is less satisfied with their jobs compared to previous generations. In their research Bencsik, Horváth-Csikós and Juhász (2016) then emphasizes that members of generations $\mathrm{Y}$ and $\mathrm{Z}$ tend to evaluate themselves far more positively than older generations. If we were to generally assess what is important for individuals in relation to employment, regardless of generation, we would have to list a range of factors, including the ability to learn and develop, the ability to participate in decision-making, work-life balance, the opportunity to apply innovation and independence, friendly environment and good working relationships, diversity and cosmopolitan nature of the team, work that is a challenge and that is in the field studied, the amount and setting of wages or a wide range of benefits (Šnýdrová, Vnoučková and Šnýdrová, 2019; Donia and Tetrault Sirsly, 2016; Jones, Willnessan and Madey, 2014; Rampl 2014, Rupp et al., 2013). However, the evaluation of the significance and order of individual factors from the point of view of individual generations differs. Generational differences between career goals and expectations of generations $\mathrm{X}, \mathrm{Y}$ and $\mathrm{Z}$ are considerable (Deloitte, 2020; Ismail et al., 2016; Turner, 2015).

While the generation $\mathrm{X}$ perceives financial rewards as a value, i.e., it is the goal of their job, the generation $\mathrm{Y}$ sees it as a way to fulfill their desires and goals (Horváthová and Čopíková, 2015). Financial remuneration is more important for generation $\mathrm{X}$ than for generation $\mathrm{Y}$. Generation $\mathrm{X}$ also considers the employer's importance of a good atmosphere, the possibility of continuous improvement, or the stability of employment (Gadomska-Lila, 2020; Horváthová and Čopíková, 2015).

The younger generation prefers social values and emphasizes attractivity and fun in their job and the benefit to society (Twenge et al, 2010; Ferri-Reed, 2010). Generation Y also puts more emphasis on non-financial remuneration than generation $\mathrm{X}$. Generation $\mathrm{Y}$ needs change, and this generation changes jobs once there is an interesting opportunity (Twenge et al. 2010). Millennials expect a faster career shift than the older generation and tend to seek out employers that enable it (Saba, 2013). Millennials further have higher expectations and demands for different career options (Lyons and Kuron, 2014). On the other 
hand, it is worth mention that there is an overall shift in the view of career development. Although the traditional concept of career in terms of vertical development still prevails, many employees prefer horizontal career, towards deepening responsibility or changing positions or disciplines (Kirovová, 2011). Especially members of the generation $Y$ are considered to be motivated by job flexibility and interestingness of work and prefers the possibility of competency development (Kirovová, 2011). Research shows that ambitions represent the dealbreaker for $\mathrm{Y}$ generation. Ambitions play also a significant role in career evaluation (Judge and Kammeyer-Muelle, 2012; Spurk and Abele, 2011). Members of this generation are motivated to stay and work for current employer only if they are allowed to enter a higher level in organizational structure, into management and develop their career and to be able to get a rapid shift in the career. The other following areas are primarily assessed: wage / salary, job position and prestige (Judge and Kammeyer-Muelle, 2012; Spurk and Abele, 2011). Furthermore, the possibility of development, fulfillment of personal interests or fair treatment is important for them (Gadomska-Lila, 2020).

Members of the $\mathrm{Z}$ generation approach to employment even more specifically, as they choose a job position or career only according to their interests and do not reflect the requirements of other people (Bencsik, Horváth-Csikós and Juhász, 2016). This attitude shapes their view of the world they want to change, they are called the first completely global generation (Iorgolescu and Samuels, 2015). On the other hand, they are less optimistic than previous generations when looking at the labor market and their employment (Bencsik, HorváthCsikós and Juhász, 2016).

Like members of generation $\mathrm{Y}$, members of generation $\mathrm{Z}$ prefer home offices and place even greater emphasis on the possibility of using digital technologies in working life (Delloitte, 2020; Bencsik, Horváth-Csikós and Juhász, 2016; Gursoy, Geng-Quing Chi and Karadag 2013). Stability and adequate financial rewards are also important aspects for generation Z (Deloitte, 2020; Bencsik, Horváth-Csikós and Juhász 2016). They constantly need new impulses and challenges, which is also confirmed by Kubátová (2016), who mentions in her research that a large percentage (almost $1 / 4$ ) of members of the $Z$ generation see their career in their own business. They are looking for a job where they could show their independence, but at the same time, they like working in a team (Gadomska-Lila, 2020; Iorgolescu and Samuels 2015). They are able to work on multiple tasks at once, which they take for granted. To define their preferable employment, it is important to mention: development opportunities, maintaining appropriate work, a pleasant atmosphere, freedom, a sense of recognition, work-life balance (Gadomska and Lila, 2020 Iorgolescu and Samuels 2015).

However, Kunze, Boehm and Bruch (2013) mention in their research on age stereotypes that it is necessary to take into account individual preferences in career settings and goals because this is a highly individual area. Authors also note that research has shown a more positive approach to change among older workers than younger workers.

\section{Attitudes to the contribution of university studies in relation to employment}

According to research, the main benefit of studying at a university is the possibility of a better job in connection with a higher position and a higher salary (Vnoučková, Smolová and Depoo, 2019; Fryer et al, 2016). Fryer et al. (2016) cite other reasons associated with the desire to achieve higher education, including the desire for wealth and material security, the desire to acquire or deepen knowledge and skills, or to obtain a university degree. In his research, O'Leary (2017) also points to significant differences between the generations in assessing the benefits of higher education.

In connection with the growing interest in tertiary education, it is necessary to mention that the number of university graduates is growing in the Czech Republic, which is positive, but at the same time, the number of jobs suitable for university students is not growing, i.e., places where they could make full use of knowledge at university, which is a negative factor (Zelenka, 2019).

Thus appears an interesting phenomenon when the university degree has become almost a necessity to be able to get a valuable job, but, on the other hand, it is often required in positions that do not correspond to university knowledge by their nature (Mavromaras and McGuiness, 2012). The term Overeducation is thus becoming increasingly common (Maršíková and Urbánek, 2015). This is also associated with a lower financial remuneration of these positions, respectively of those employees who hold them (Salahodjaev, 2015, Mavromaras and McGuiness, 2012). In some cases, there is a paradoxical situation where graduates hold positions that require neither knowledge which they have acquired during their university studies, nor a university degree (SánchezSánchéz and McGuiness, 2015). Koucký and Zelenka (2011) in their research mention a weaker or missing relationship towards occupied job positions or fields of employment by current graduates in the Czech Republic. Zelenka (2019) states that some individuals hold positions that do not correspond to the field of study and therefore the employee will not use the acquired knowledge and skills.

\section{MATERIALS AND METHODS}

The article consists of a theoretical introduction, which was elaborated on the basis of an analysis of scientific articles and publications. Publications and articles were searched electronically using keywords such as age, age group, attitudes, generation X, Y and Z, graduate, labor market, job placement, etc. The questionnaire focused on attitudes of graduates in case business university towards work conditions, work environment and conditions of job position. The survey had 31 questions and was composed of multiple-choice questions and open questions. The loadings of responses were binary or qualitative answers (categorical variables). The type of variables was in all cases nominal as respondents were checking boxes for statements relevant for their perception and experiences, e.g., in the case of financial remuneration, the answers were: sufficient/insufficient. Questions related to attitudes towards preferred employer (Table 2) each graduate was checking whether each criterion is important/ 
not important for the choice of his/her future or preferred employer. Benefits of graduation by generations were also picked by respondents as perceived/not perceived (Table 3.) At first part, Table 3 shows the implication of university education and graduation with a degree in practice (variables A). The second half of Table 3 shows shift in knowledge, skills and abilities after successfully passing university study program (variables B). Respondents always picked one of binary answer: perceived/not perceived. The tested questions in Table 4 were: H02: Higher education was required for your current job position? With binary answer Yes/No and H03: Do you currently work in the studied area? Answers were Yes/No. Other questions in the questionnaire were searching the following areas: work in the studied area, the sufficiency of financial remuneration and benefits, the necessity to be graduated for the current job position, preferences while seeking the job and preferred employer, level of university education and its ability to transfer knowledge and skills to practice, which competences they need for current job, whether those competences were trained and taught during their studies, which changes they perceived after graduation related to job and career, which benefits of higher education they perceive in practice, which competences they gained during studies or were significantly improved (according to respondent's opinion). Only questions described above were analyzed in this paper.

The questionnaires were sent out electronically and data processed by computer. After collection, the data were cleared and further tested.

The University's alumni list was used to contact graduates in order to fill electronic survey. All graduates of a private business university in the Czech Republic were contacted. The university is divided into the following departments: Human Resources, Marketing, Economics, Management, and Business. Graduates in the four past academic years were contacted. In total, 400 graduates were contacted. The total return was 175 full responses, i.e., $43.7 \%$ of the total sample. The sample is representative for the given university.

The impact of $\mathrm{X}, \mathrm{Y}$ and $\mathrm{Z}$ generation (age of graduates) on the evaluation of selected factors influencing the graduates' job performance expressed by the level of their job position was tested. Furthermore, the following propositions were tested based on generation of graduates: work in the field of study, perception of financial remuneration as appropriate and working at the position for which higher education is required.

Based on the theoretical analysis of the searched issues, five hypotheses were formulated:

$\mathrm{H} 01$ There is no difference between generations $\mathrm{X}, \mathrm{Y}$ and $\mathrm{Z}$ and attitudes towards employment.

$\mathrm{H} 02$ : There is no difference between generations $\mathrm{X}, \mathrm{Y}$ and $\mathrm{Z}$ and holding a position where higher education is not required. $\mathrm{H} 03$ : There is no difference between generations $\mathrm{X}, \mathrm{Y}$ and $\mathrm{Z}$ and working in the studied area.

$\mathrm{H} 04$ : There is no difference between generations $\mathrm{X}, \mathrm{Y}$ and $\mathrm{Z}$ and evaluation of benefits of higher education in practice. $\mathrm{H} 05$ : There is no difference between generations $\mathrm{X}, \mathrm{Y}$ and $\mathrm{Z}$ and evaluation of shift in thinking after graduation.
All hypotheses were formulated as null hypotheses declaring the non-existence of the relationship. The Chi-square test of independence for each variable was used to compare differences between generations to determine whether two categorical or nominal variables are likely to be related or not. Always, two variables were observed for each observational unit. The conditions for use of this test were met: the sampling method was simple random sampling. The variables under study are categorical. The expected value of the number of sample observations in each level of the variable is at least 5. We used chi-square test of independence to compare differences between generations, e.g., we tested always gen $\mathrm{X}$ with $\mathrm{Y}$ and $\mathrm{Z}$ and in case both tests have shown significant differences we used the result The tests used were performed at the significance level of 0.05 . IBM SPSS statistical software was used for data processing and analysis.

Based on the theoretical background, it was determined that the groups 20-25 years (51 respondents) are classified as generation $\mathrm{Z}, 26-30$ years, and 31-45 years are classified into generation Y (109 respondents). Group 45 years and more in generation $\mathrm{X}$ (76 respondents). The groups of respondents were tested according to the generation they belong to.

The structure of respondents at the time of their graduation was the following:

- Generation Z: age group 20-25 years contained 51 respondents $(21.6 \%)$, from this age group there were 9 men $(3.8 \%)$ and 42 women $(17.8 \%)$

- Generation Y: age group 26-45 years (109 respondents, $46.2 \%)$; from this age group there were 63 women $(26.7 \%)$ and 46 men $(19.5 \%)$

- Generation X: age group 46 and over (76 respondents, $32.2 \%$ ); from this age group there were 50 women $(21.2 \%)$ and 26 men $(11.0 \%)$

We need to keep in mind that this case study has several limits: the respondents took the survey only on voluntary. It is also necessary to mention that the analyzed generation $\mathrm{Z}$ in our sample had less respondents, as this generation is now entering the group of graduates, based on their young age. On the other hand, this study is bringing first results and insights, which will be further studied in the future as this generation will broaden its numbers. Despite mentioned limitations, it is possible to state that the sample is representative for this case study, as respondents were formed from different backgrounds, represents all studied generations, and work on different jobs. Moreover, their affiliation to the generations under examination is undisputed and their number is sufficient. The tests shown the sample is significant and representative for our case university and thus may be taken as a case study on representative sample of business graduates.

\section{RESULTS}

The results of this paper focus on testing and identifying the differences in generations in selected factors based on successful graduation at business university. The outputs indicate the significant role of generation in higher education in investigated variables affecting the employability of graduates on the job market. Statistical tests were run in 
the areas of the field of business and job characteristics and approaches of graduates to the job environment (possibility for development, participation in the decisionmaking process, work-life balance, innovative and creative environment, diversified collective with cosmopolitan coworkers, development possibilities, friendly relationships at work, independence, responsibility, flow, challenging work, work in studied area, remuneration and benefits). Each of these factors were analyzed and tested separately in relation to generation differences.
Table 2 shows the classification of frequencies (absolute and relative) by generation for each tested variable. The proportion per each generation and variable is presented. As we may see in Table 2, variables vary in several cases for each generation. Table 2 shows firstly frequencies, the statistical testing of differences between generations is shown in Table 4 .

Overall, graduates are oriented mostly towards development possibilities, positive relationships at the workplace, flow (interest in their job tasks and seeing them as fulfilling, having a job as a hobby), and, of course remuneration is still very important.

\begin{tabular}{lc|c|c|c|cc}
\hline & \multicolumn{2}{|c|}{ Generation Z } & \multicolumn{2}{c|}{ Generation Y } & \multicolumn{2}{c}{ Generation X } \\
\multicolumn{1}{c}{ Preferred work conditions } & Abs. & Rel. & Abs. & Rel. & Abs. & Rel. \\
\hline Work abroad & 4 & 7.84 & 19 & 17.43 & 3 & 3.95 \\
\hline Development possibilities & 31 & 60.78 & 83 & 76.15 & 46 & 60.53 \\
\hline Participation at decision-making & 4 & 7.84 & 25 & 22.94 & 22 & 28.95 \\
\hline Work-life balance & 23 & 45.10 & 63 & 57.80 & 42 & 55.26 \\
\hline Innovative opportunities & 17 & 33.33 & 50 & 45.87 & 33 & 43.42 \\
\hline Cosmopolitan collective & 3 & 5.88 & 22 & 20.18 & 12 & 15.79 \\
\hline Development programs & 17 & 33.33 & 33 & 30.28 & 9 & 11.84 \\
\hline Friendly relationships & 34 & 66.67 & 75 & 68.81 & 39 & 51.32 \\
\hline Independence & 14 & 27.45 & 38 & 34.86 & 40 & 52.63 \\
\hline Flow & 36 & 70.59 & 83 & 76.15 & 48 & 63.16 \\
\hline Challenging job & 15 & 29.41 & 46 & 42.20 & 22 & 28.95 \\
\hline Job related to studies & 11 & 21.57 & 15 & 13.76 & 18 & 23.68 \\
\hline Remuneration & 34 & 66.67 & 78 & 71.56 & 32 & 42.11 \\
\hline Broad benefits & 13 & 25.49 & 36 & 33.03 & 18 & 23.68 \\
\hline
\end{tabular}

Table 2: Attitudes of graduates by generation (source: own processing)

The results presented in Table 2 show that among generation $\mathrm{Z}$ compared to generations $\mathrm{Y}$ and $\mathrm{X}$, the most important variables are development programs and remuneration. Other factors are usually seen as more important for older generations or fluctuating around similar value.

Generation Y (compare to younger and older generation) focuses mostly on development possibilities, work-life balance, innovative opportunities, relationships at the workplace, flow, challenges, remuneration and benefits. These results indicate at the current most active generation which is in productive age and having families, thus the need for balance in their life and they also value challenges, innovations and growth.

Respondents from generation $\mathrm{X}$ (the oldest generation in the sample) accents the most independence in their job, participation in decision-making and close connection between job and studied program. Respondents from this generation are already skilled workers with long career history and thus they aspirate at leading positions. Based on that they attitudes are oriented toward managerial opportunities (decision-making, independence) the most of all searched generations.

It is possible to see that generation $\mathrm{Y}$ is certainly the most active generation with clear approaches towards their job positions after graduation, who accents work abroad, development possibilities, work-life balance, innovative opportunities, cosmopolitan collective, friendly relationships, flow, challenging job, remuneration, and benefits.

Table 3 shows the benefits of graduation by generations. The first part shows the implication of university education and graduation with a degree in practice (variables A) and the second half of Table 3 shows shift in knowledge, skills and abilities after successfully passing a university study program (variables B). The main benefits of university graduation are seen in gaining better status, deeper knowledge, general overview and ability to search and evaluate information. Table 3 shows firstly frequencies, the statistical testing of differences between generations is shown in Table 4 .

The results in Table 3 describe the attitudes of case university graduates towards their shift in job or labor market after graduation and also the perceived upgrade of their skills, abilities and knowledge (statistical differences among generations are shown in Table 4). The table shows absolute and relative frequencies of respondents' replies. It is possible to mention partial differences between generations. For example, a better lifestyle based on university graduation is perceived most by generation $\mathrm{Z}(22 \%)$ compare to generation Y $(14 \%)$ and generation X (8\%). A similar result can be seen in the case of critical thinking. Generation $\mathrm{Z}$ stated the shift in thinking in $25 \%$, generation $\mathrm{Y}$ in $18 \%$ and generation $\mathrm{X}$ in $11 \%$. The same trend can be seen in case of variables "Ability to find information" and "Data and information evaluation". These variables are also mostly pointed out by generation $\mathrm{Z}$, less by generation $\mathrm{Y}$ and least by generation $\mathrm{X}$. This shows that university shapes mostly the youngest students and giving them better perceived lifestyle, ability to think critically and search for information and evaluate them compare to older students. Students with several years of experience in practice 
evaluated these benefits in the lower number of cases as they were already skilled in searching for information and critical thinking from their previous work and life experience.

The opposite trend may be found in variables "Deeper knowledge", "Analytical skills" and "General overview". Those benefits of university graduation were mostly recognized by older students (generation Y and mainly by generation X). This shows appreciation of older students who are coming back to studies after years in practice. Those students get a broader insight into a current studied area which is showing them a wide range of things compare to their narrow specialization at their jobs. They gained and value new knowledge and skills compare to those they had before and used in their workplace. Other variables are oscillating around similar values for all generations. Interestingly, it is possible to mention, that only a few percent of respondents indicated also non-financial rewards as a benefit after their graduation. This area is still not fully used in the current Czech job market. On the other hand, due to changes related to COVID-19, this area will probably be on its rise.

In relation to the requirements for higher education, we may state that the results are more balanced. $40.78 \%$ of graduates work in positions where higher education is required and $59.22 \%$ of all respondents said that they work in a position that does not require higher education. An interesting finding of primary research is that $63.59 \%$ of respondents after graduation remained in the field of study, while the number of graduates who changed the field and work in a completely different field is almost half lower $(36.41 \%)$. The same ratio of answers occurs in relation to the evaluation of the amount of salary corresponding to the position held. Most respondents are satisfied with the amount of wages and rate it as adequate $(60.19 \%)$ and $39.81 \%$ of respondents rate the amount of their wages as inadequate. A relatively high percentage of graduates work completely outside the field of study and for a salary that the respondents themselves consider to be inadequate.

The results obtained from the primary survey were further statistically tested in order to keep the hypothesis stated based on the literature valid or to reject them. The Chisquare independence test was used to determine whether two categorical variables are likely to be related or not. Results are shown in Table 4. Hypotheses were rejected only when all questions investigated per each hypothesis shown significant differences between generations. In order to display the results in Table 4, we always run the test between results of generation $\mathrm{X}$ and $\mathrm{Y}$, then between $\mathrm{Y}$ and $\mathrm{Z}$ and finally between $\mathrm{Z}$ and $\mathrm{X}$. Only when all results were statistically significant, we rejected the hypothesis.

\begin{tabular}{l|r|r|r|r|rr} 
& \multicolumn{2}{|c|}{ Generation Z } & \multicolumn{2}{c|}{ Generation $\mathbf{c}$} & \multicolumn{2}{c}{ Generation $\mathbf{X}$} \\
\hline \multicolumn{1}{c}{ Benefits after graduation } & Abs. & Rel. & Abs. & Rel. & Abs. & \multicolumn{1}{c}{ Rel. } \\
\hline A. Career move & 8 & 15.69 & 30 & 27.52 & 17 & 22.37 \\
\hline A. Better status & 19 & 37.25 & 42 & 38.53 & 26 & 34.21 \\
\hline A. Better salary & 11 & 21.57 & 23 & 21.10 & 17 & 22.37 \\
\hline A. Better life style & 11 & 21.57 & 15 & 13.76 & 6 & 7.89 \\
\hline A. Better position & 9 & 17.65 & 18 & 16.51 & 13 & 17.11 \\
\hline A. Better non-financial rewards & 2 & 3.92 & 3 & 2.75 & 4 & 5.26 \\
\hline B. Deeper knowledge & 25 & 49.02 & 53 & 48.62 & 41 & 53.95 \\
\hline B. Critical thinking & 13 & 25.49 & 20 & 18.35 & 8 & 10.53 \\
\hline B. Data and information evaluation & 29 & 56.86 & 52 & 47.71 & 20 & 26.32 \\
\hline B. Analytical skills & 11 & 21.57 & 24 & 22.02 & 22 & 28.95 \\
\hline B. Ability to find information & 27 & 52.94 & 51 & 46.79 & 23 & 30.26 \\
\hline B. General overview & 25 & 49.02 & 28 & 25.69 & 46 & 60.53 \\
\hline
\end{tabular}

Table 3: Benefits of graduation by generation (source: own processing)

\begin{tabular}{|c|c|c|}
\hline & Chi-square test $p$-value & Evaluation of hypotheses \\
\hline $\begin{array}{l}\text { H01: There is no difference between generation } \mathrm{X}, \mathrm{Y} \text { and } \mathrm{Z} \text { and attitudes toward } \\
\text { job characteristics. (variables displayed in Table 2) }\end{array}$ & $<0.001$ & Rejected \\
\hline $\begin{array}{l}\mathrm{H} 02^{* *} \text { : There is no difference between generation } \mathrm{X}, \mathrm{Y} \text { and } \mathrm{Z} \text { and requirement for } \\
\text { higher education. }\end{array}$ & $<0.001$ & Rejected \\
\hline $\begin{array}{l}\text { H03**: There is no difference between generation } X, Y \text { and } Z \text { and working in the } \\
\text { studied area. }\end{array}$ & $<0.001$ & Rejected \\
\hline $\begin{array}{l}\text { H04: There is no difference between generations } \mathrm{X}, \mathrm{Y} \text { and } \mathrm{Z} \text { and evaluation of } \\
\text { benefits of higher education in practice. (variables displayed in Table 3, part A) }\end{array}$ & $<0.001^{*}$ & Rejected* \\
\hline $\begin{array}{l}\text { H05: There is no difference between generations } \mathrm{X}, \mathrm{Y} \text { and } \mathrm{Z} \text { and evaluation of shift } \\
\text { in thinking after graduation. (variables displayed in Table } 3 \text {, part B) }\end{array}$ & $<0.001$ & Rejected \\
\hline
\end{tabular}

* Significant difference found only between generations $X$ and $Z$

** HO2 and HO3 were tested on other questions which formed part of the questionnaire but were not displayed in Table 2 and 3. The tested questions were: H02: Higher education was required on your current job position? (Yes/No) and H03: Do you currently work in the studied area? (Yes/No).

Table 4: Differences between attitudes of generations (source: own processing) 
Table 4 presents the results of statistical testing of set hypotheses. The results for all five tested hypotheses show statistically significant differences between generations of respondents. Hypotheses 1, 2, 3 and 5 were rejected as there are statistically significant differences between all three generations. In case of hypothesis 4, there is the statistically significant difference only between generations $\mathrm{X}$ and $\mathrm{Z}$. Based on these findings, it can be stated that belonging to generation $\mathrm{X}, \mathrm{Y}$ or generation $\mathrm{Z}$ plays important role in the attitudes toward job characteristics, requirements for higher education, and working in the studied area. The same result was found in the case of a shift in thinking after passing university program and graduating. Differences in the evaluation of benefits of higher education in practice were found only between generation $\mathrm{X}$ and $\mathrm{Z}$. There are no statistically significant differences between generations that are closer in their age characteristics (e.g., between $\mathrm{Y}$ and $\mathrm{Z}$ and between $\mathrm{X}$ and $\mathrm{Y}$ ). Statistical testing thus confirms the overall results, which show generational differences in the application of university degree in practice and their life change. Despite long-term studies and increase in the qualifications of respondents from all generations, there are still differences in their attitudes, knowledge, positions and application.

Based on the obtained results regarding job position and level of education of graduates we tested relations between obtained position and graduates' abilities. The purpose was to find significant abilities required from graduates. Respondents indicated whether they need and use creativity and teamwork or other variables at their job position. Those answers were put into the analysis. Results of analysis show that there are neither significant relations between the position of graduates nor working in the field of study. On the other hand, significant relations were found in the area of remuneration and requirement of higher education. The perception of financial remuneration as appropriate correlates with creativity, but the correlation is weak $(r=0.172, p=0.014)$. The same result was found between the requirement of higher education and the ability to teamwork $(r=0.172, p=0.014)$. It is possible to induce that creative graduates easily find job opportunities that remunerate their effort accordingly. Further relations with creativity were found in case of innovativeness (moderately strong correlation $r=0.455, p<0.001$ ), goal orientation (weak to moderate correlation $r=0.260, p<0.001$ ), ability to motivate others shown weak to moderate correlation $(r=0.243, p=0.001$ ), and also ability to teamwork (weak to moderate correlation $r=0.201, p=0.004$ ). Furthermore, the ability to teamwork correlates with responsibility (weak to moderate correlation $r=0.242, p<0.001$ ). Presented relations are shaping the requirements on graduates' abilities in the current work environment. There is a necessity of creativity, innovativeness, teamwork, goal orientation and the ability to motivate others.

The results suggest that in order to get better higher education producing efficient graduates, teaching should meet the needs of graduates to enable them to improve their abilities for job performance. Teachers should encourage students to actively participate in the process of gaining abilities.

\section{DISCUSSION}

The results of the primary research showed differences between the attitudes of members of individual generations to employment. The attitudes of the respondents to the following factors influencing their choice of job position, which are: Work abroad, Development possibilities, Participation at decision-making, Work-life balance, Innovative opportunities, Cosmopolitan collective, Development programs, Friendly relationships, Independence, Flow, Challenging job, Job related to studies, Remuneration, Broad benefits. Members of the $\mathrm{Z}$ generation rate Flow $(70.59 \%)$ as the most important, followed by a friendly environment $(66.67 \%)$ and remuneration $(66.67 \%)$ and in fourth place Development possibilities $(60.78 \%)$. On the contrary, members of generation $\mathrm{Y}$ value it the most Development possibilities (76.15\%) and Flow, (76.15\%) followed by remuneration $(71.56 \%)$ and the friendly environment (68.81\%). For members of generation $\mathrm{X}$, the most important is Flow (63.15\%), followed by Development possibilities (60.53\%), work-life balance (55.26\%) and Independence (52.63\%). It is interesting that the financial evaluation, which, as important for Generation X, is presented by Horváthová and Čopíková (2015), does not appear among the four most important factors related to employment in primary research. Conversely, in the case of generations $\mathrm{Y}$ and $\mathrm{Z}$, there is consistency in the importance of financial evaluation with other research (e.g. Deloitte, 2020; Bencsik, Horváth-Csikós and Juhász, 2016; Judge and Kammeyer-Muelle 2012; Spurk and Abele, 2011). The attitudes of generations thus differ in the evaluation of individual factors, however, it must be stated that the research clearly shows that within all three generations one of the four most important factors are development possibilities, which is in line with what they state in their research GadomskaLila (2020) or Iorgolescu and Samuels (2015). The same result is related to friendly relations that are mentioned by Deloitte (2020); Bencsik, Horváth-Csikós and Juhász, (2016) or Horváthová and Čopíková, (2015). An interesting finding from the primary research is that a relatively small proportion of respondents consider it important that the job position corresponds to the field of study, as this aspect was considered important by only $23.68 \%$ of respondents from generation X, two percent less $(21.57 \%)$ of respondents of generation $\mathrm{Z}$ and only $13.76 \%$ of respondents from generation Y. These results confirm the findings of Kaucký and Zelenka (2011) or Zelenka (2019), i.e. that a relatively large percentage of graduates are willing to work outside the field of study or in a position that does not require a university degree.

When evaluating the benefits of obtaining a university degree, there are again generational differences, because while generation $\mathrm{Z}$ evaluates it as the most beneficial Data and information evaluation (56.86\%), generation Y Deeper knowledge (48.62\%) and generation $\mathrm{X}$ as the most beneficial considers the acquisition of a general overview (60.53\%). Respondents also differ over generations in the other benefits of a university degree examined for employment, which is in line with what O'Leary (2017) states in his research.

It is also necessary to mention that the analyzed generation $\mathrm{Z}$ in our sample had less respondents, as this generation is now 
entering the group of graduates, based on their young age. On the other hand, this study is bringing first results and insights, which will be further studied in the future as this generation will broaden its numbers.

\section{CONCLUSION}

The labor market is changing with the advent of generation $\mathrm{Z}$ and thus the new distribution of the workforce between the three generations $\mathrm{X}, \mathrm{Y}$, and the aforementioned generation $\mathrm{Z}$. In this context, research by employers, universities, and other professionals focus on the different attitudes of members of these generations to employment and to evaluating the contribution of higher education to employment. Only in this way is it possible to reflect on these attitudes and thus better address or stabilize individual employees. It can be expected that the situation regarding employment of graduates will further develop in connection with changes in the labor market, which reflects not only the aforementioned generational distribution of workers but also the situation associated with the effects of the COVID-19 pandemic. The results of the primary research clearly showed differences in the attitudes of members of the individual generations studied (X, Y and $\mathrm{Z}$ ) in attitudes to employment as well as in attitudes to the contribution of higher education in relation to employment. All established hypotheses were rejected on the basis of research and subsequent statistical testing.
The debate on the contribution of university education is important and needs to be highlighted. Our research outcomes indicated that graduates perceived benefits are directly related to data and information evaluation to obtain deeper knowledge and acquire a general overview. The result reveals that graduates confirmed that they are receiving value of their degree.

In this study, it is important to mention its limits. Firstly, it is a narrow focus on one case university which is predominantly business in its focus. On the other hand, the outputs are presented as an indicative approach of generations of graduates. Secondly, it is the low number of generation $\mathrm{Z}$ graduates. This is due to overall low number of graduates in general, as those are still too young to graduate. This study brings first approaches and the number of generation $\mathrm{Z}$ graduates and their research will follow. Based on shown findings it may support other HEIs in curricula development and adjustment for new generations, as well as to employers to attract generations at labor market. Our article also provides an insight into the importance of focus on expectations of the different generation and the necessity of continuous development and realization of improvements based on changing generational preferences.

Further research would be appropriate and interesting to focus on the impact of the COVID 19 pandemic on the expectations and applicability of university graduates. This study can be expanded to other universities and organizations. Further, revealed differences may be validated at other HEIs and in praxis.

\section{REFERENCES}

Anderson, H. J., Baur, J. A., Griffith, J. A. and Buckley, M. R. (2017) 'What works for you may not work for (Gen)Me: Limitations of present leadership theories for the new generation', The Leadership Quarterly, Vol. 28, No. 1, pp. 245-260. https://doi. org/10.1016/j.leaqua.2016.08.001

Becton, J. B., Walker, H. J. and Jones-Farmer, A. (2014) 'Generational differences in workplace behavior', Journal of Applied Social Psychology, Vol. 44, No. 3, pp.175-189. https://doi.org/10.1111/ jasp. 12208

Benson, J. and Brown, M. (2011) 'Generations at work: are there differences and do they matter?', The International Journal of Human Resource Management, Vol. 22, No. 9, pp. 1843-1865. https://doi.org/10.1080/09585192.2011.573966

Bencsik, A., Horváth-Csikós, G. and Juhász, T., (2016) 'Y a Z generation in Workplace', Journal of Competitiveness, Vol. 8, No 3, pp. 90-06. https://doi.org/10.7441/joc.2016.03.06

Deloitte (2020) Survey: Deloitte MillenialSurvey, [online], Available: https://www2.deloitte.com/content/dam/Deloitte/global/ Documents/About-Deloitte/deloitte-2020-millennial-survey.pdf [8 Jan 2021].

Donia, M. B. L. and Tetrault Sirsly, C. A. (2016) 'Determinants and consequences of employee attributions of corporate social responsibility as substantive or symbolic', European Management Journal, Vol. 34, No. 3, pp. 232-242. https://doi. org/10.1016/j.emj.2016.02.004

Campbell, S., M., Twenge, J., M. and Campbell, W. K. (2017) 'Fuzzy But Useful Constructs: Making Sense of the Differences Between Generations', Work, Aging and Retirement, Vol. 3, No 2, pp.130139. https://doi.org/10.1093/workar/wax001
Czech Statistical Office. (2019) Miry zaměstnanosti, nezaměstnanosti a ekonomické aktivity - ř́jen 2019 [Employment, unemployment and economic activity rates - October 2019], [Online], Available: https:// www.czso.cz/csu/czso/cri/miry-zamestnanosti-nezamestnanosti-aekonomicke-aktivity-rijen-2019 [19 Oct 2020].

Ferri-Reed, J. (2010) 'The keys to engaging millennials', Journal for Quality and Participation, Vol. 33, No.1, pp. 31-33.

Fryer, L. K., Van den Broeck, A., Ginns, P. and Nakao, K. (2016) 'Understanding Students' Instrumental Goals, Motivation Deficits and Achievement: Through the Lens of a Latent Profile Analysis', Psychologica Belgica, Vol. 56, No. 3, pp. 226-243. http://doi. org $/ 10.5334 / \mathrm{pb} .265$

Glazer, S., Mahoney, A. C. and Randall, Y. (2019) 'Employee development's role in organizational commitment: a preliminary investigation comparing generation $\mathrm{X}$ and millennial employees', Industrial and Commercial Training, Vol. 51, No. 1, pp. 1-12. https://doi.org/10.1108/ICT-07-2018-0061

Gadomska-Lila, K. (2020) 'Value Systems of Various Generations', Human Resource Management / Zarzadzanie Zasobami Ludzkimi, Vol.133 No.2,pp.27-40.https://doi.org/10.5604/01.3001.0014.0731

Gurau, C. (2012) 'A life-stage analysis of consumer loyalty profile: comparing Generation X and Millennial consumers', Journal Consumer Marketing, Vol. 29, No. 2, pp. 103-113. https://doi. org/10.1108/07363761211206357

Gursoy, D., Geng-Quing Chi, Ch., and Karadag. (2013) 'Generational differences in work values and attitudes among frontline and service contact employees', International Journal of hospitality management, Vol. 32, pp. 40-48. http://dx.doi.org/10.1016/j. ijhm.2012.04.002 
Horváthová, P. and Čopíková, A. (2015) 'Generation Y and its impact on the performance of personnel activities', 15th International Scientific Conference on Globalization and its socio-economic consequences, Žilina, pp. 218-223.

Iorgolescu, M. C. (2016) 'Generation Z and its perception of work', Cross-Cultural management Journal, Vol. 18, No. 1, pp. 47-54.

Ismail, M., Rahim, A. N. A., Lee, K. H. and Mohd Thahrir, N. F. (2016) 'Cultural values and career goals of gen-X and gen- $Y$ employees: evidence from selected Malaysian companies', Organizations and Markets in emerging economies, Vol. 7, No. 2, pp.43-64. https://doi.org/10.15388/OMEE.2016.7.2.14207

Jones, D. A., Willness, C. R. and Madey, S. (2014) 'Why are job seekers attracted by corporate social performance? Experimental and field tests of three signal-based mechanisms', Academy of Management Journal, Vol. 57, pp. 383-04. https:// doi.org/10.5465/amj.2011.0848

Judge, T. A. and Kammeyer-Mueller, J. D. (2012) 'On the value of aiming high: The causes and consequences of ambition'. Journal of Applied Psychology, Vol. 97, No. 4, pp. 758-775. https://doi.org/10.1037/a0028084

Kirovová, I. (2011) 'Od tradiční kariéry k současným kariérním koncepcím’, Československá Psychologie, Vol. 55, No. 4, pp. $316-331$.

Kopecký, L. (2013) Public relations, Déjiny-teorie-praxe [Public relations, history-theory-practice], Prague: Grada Publishing.

Koucký, J. and Zelenka, M. (2011) Postavení vysokoškoláki̊ a uplatněni absolventů vysokých škol na pracovnim trhu 2011 [Position of university students and employment of university graduates on the labour market], Prague: Středisko vzdělávací politiky, Univerzita Karlova v Praze.

Krahn, H. J. and Galambos, N. L. (2014) 'Work values and beliefs of 'Generation X' and 'Generation Y', Journal of Youth Studies, Vol. 17, No. 1, pp. 92-112. https://doi.org/10.1080/1 3676261.2013.815701

Kunze, F., Boehm, S. and Bruch, H. (2013) 'Age, resistance to change, and job performance', Journal of Management Psychology, Vol. 28, No. 7-8, pp. 741-760. https://doi. org/10.1108/JMP-06-2013-0194

Kubátová, J. (2016) 'Work-Related Attitudes of Czech Generation Z: International Comparison', Central European Business Review, Vol. 5, No. 4, pp. 61-70. https://doi.org/10.18267/j. cebr. 167

Kuron, L. K. J., Lyons, S. T., Schweitzer, L. and Ng, E. S. W. (2015) 'Millennials' work values: differencies across the school to work transition', Personnel Review, Vol. 44, No. 6, pp. 991-1009. https://doi.org/10.1108/PR-01-2014-0024

Lee, Y.-J. and Haley E. (2020) 'How Do Generational differences Drive Response to Social -Issue Ads? The Effect of Value Orientations Across Generations in the U.S', Journal of Advertising Research, Vol. 60, No. 3, pp. 271-289. https:// doi.org/10.2501/JAR-2019-013

Lyons, S. T. and Kuron, L. (2014) 'Generational differences in the workplace: A review of the evidence and directions for future research', Journal of Organizational Behavior, Vol. 35, No. S1, pp. 139-157. https://doi.org/10.1002/job.1913

Maršíková, K and Urbánek, V. (2015) ‘A comparison of educational mismatches across Europe', Ekonomie and Management, Vol. 18, No. 4, pp. 24-38. https://doi.org/10.15240/tul/001/2015$\underline{4-002}$
Malik, S. and Khera S.N. (2014) 'New generation -great expectations Exploring the work attributes of gen y', Global Journal of Finance and Management, Vol. 6, No. 5, pp. 433438.

Mavromaras, K. and McGuinness, S. (2012) 'Overskilling dynamics and education pathways', Ecoomics of Education Review, Vol.31, No. 5, pp. 619-628. https://doi.org/10.1016/j. econedurev.2012.02.006

Ng, E. S., and McGinnis-Johnson, J. (2015) 'Millennials: Who are they, how are they different, and why should we care?', in Burke, R. J., Cooper, C. and Antoniou A. (ed.), The Multigenerational Workforce: Challenges and Opportunities for Organisations, pp. 121-137

Raemdonck, I., Beausaert, S., Fröhlich, D. Kochoian, N. and Meurant, C. (2015) 'Age related changes in learning and employability', in Bal, P. M., Kooij, D. T. A. M. and Rosseau, D. (ed.), Aging Workers and the Employee-Employer Relationship, pp. 163-184. Cham: Springer. https://doi. org/10.1007/978-3-319-08007-9

O'Leary, S. (2017) 'Graduates' experiences of, and attitudes towards, the inclusion of employability-related support in undergraduate degree programmes; trends and variations by subject discipline and gender', Journal of Education and Work, Vol. 30, No. 1, pp. 84-105. https://doi:10.1080/13639 $\underline{080.2015 .1122181}$

Rupp, D. E. Shao, R., Thornton, M. A. and Skarlicki, D. P. (2013) 'Applicants' and employees' reactions to corporate social responsibility: the moderating effects of first-party justice perceptions and moral identity', Personnel Psychology, Vol. 66, No. 4, pp. 895-933. https://doi.org/10.1111/peps.12030

Rampl, V. L (2014) 'How to become an employer of choice: transforming employer brand associations into employer first-choice brands', Journal of Marketing Management, Vol. 30, No. 13-14, pp. 1486-1504. https://doi.org/10.1080/ $\underline{0267257 X .2014 .934903}$

Saba, T. (2013) Understanding generational differences in the workplace: Findings and conclusions, Kingston, ON: Queen's University IRC.

Salahodjaev, R. (2015) 'Is more always good? Over-education, job satisfaction and wages on the Czech labor market', Society and economy, Vol. 37, No. 3, pp. 403-414. https:// doi.org/10.1556/204.2015.37.3.5

Rani, N. and Samuel, A. (2016) 'A study on generational differences in work values and person-organization fit and its effect on turnover intention of Generation $\mathrm{Y}$ in India', Management Research Review, Vol. 39. No. 12, pp. 16951719. https://doi.org/10.1108/MRR-10-2015-0249

Sánchez-Sánchez, N. and McGuiness, S. (2015) 'Decomposing the impacts of overeducation and overskilling on earnings and job satisfaction: an analysis using REFLEX data', Educations economics, Vol. 23., No. 4, pp. 419-432. https:// doi.org/10.1080/09645292.2013.846297

Schroth, H. (2019) 'Are You ready for generation $\mathrm{Z}$ in Workplace?', Californiam Management Review, Vol. 61, No. 3, pp. 5-18. https://doi.org/10.1177/0008125619841006

Shragay, D. and Tziner, A. (2011) 'The Generational Effect on the Relationship between Job Involvement, Work Satisfaction, and Organizational Citizenship Behavior', Revista de Psicología del Trabajo y de las Organizaciones, Vol. 27, No. 2, pp. 143-157. https://doi.org/10.5093/tr2011v27n2a6 
Schultz, R. and Schwepker, Ch. H. (2012) 'Boomers vs. Millennials: Critical Conflict Regarding Sales Culture, SalesforceRecognition, and Supervisor Expectations', International Journal of Business, Humanities and Technology, Vol. 2, No.1, pp. 32-41.

Spurk, D. and Abele, A. E. (2011) 'Who earns more and why? A multiple mediation model from personality to salary', Journal of Business and Psychology, Vol. 26, No. 1, pp. 87103. https://doi.org/10.1007/s10869-010-9184-3

Šnýdrová, M., Vnoučková, L. and Šnýdrová, I. (2019) 'Factors affecting choice of employment by university graduates', Scientific Papers of the University of Pardubice, Series D, Vol. 27, No. 2, pp. 159-170.

Twenge, J. M. Campbell, S.M., Hoffman, B.J. and Lance, Ch. E. (2010) 'Generational differences in Work Values: Leisure and extrinsic values increasing, social and intrinsic values decreasing', Journal of Management, Vol. 36, No. 5, pp.1117-1142. https://doi.org/10.1177/0149206309352246
Yi, X., Ribbens, B., Fu, L. and Weibo Cheng, L. F. (2015) 'Variation in career and workplace attitudes by generation, gender, and culture differences in career perceptions in the United States and China', Employee Relations, Vol. 37, No. 1, pp. 66-82. http://dx.doi.org/10.1108/ER-01-2014-0005

Yogamalar, I. and Samuel, A. (2016) 'Shared values and organizational citizenship behavior of generational cohorts: A Review and future directions', Management: Journal of Contemporary Management Issues, Vol. 21, No. 2, pp. 249-271.

Turner, A. (2015) 'Generation Z: Technology and Social Interest', The Journal of Individual Psychology, Vol. 71, No. 2. Pp. 103-113. https://doi.org/10.1353/jip.2015.0021

Vnoučková, L., Smolová, H. and Depoo, T. (2019) ‘The Perceived Value of Higher Business Education: A Survey of Business Students', Aula, Vol. 27, No. 1-2. pp. 20-32.

Zelenka, M. (2019) 'Massification of tertiary education and the change in the position of graduates on the labor market in the Visegrad countries', Aula, Vol. 17, No. 1-2.pp. 3-19. [in Czech] 